\title{
Study the Role of Women SHGs Members in Farm Activities and Household Consumption Pattern
}

\author{
Amresh Kumar \\ Assistant Professor, Economics, Trident B.Ed College, Gidha, Arrah, Bihar, India \\ Corresponding author: amresh880@rediffmail.com
}

Received: 27-03-2020

Revised: 18-07-2020

Accepted: 22-09-2020

\begin{abstract}
Self-Help Group is an important tool which help the rural women to acquire power for their self-supportive life. These Programme clearly play central role in the lives of the poor. SHGs is a way to raise the income level and improve the living standards and economic independence of the rural women. The impact on their lives is not just an economic one gaining more self-confidence is often a more lasting achievement that forms the basis for social and economic improvements. Rural women are the major working forces of farming activities in the study area. They regularly engaged and participated in farm activities, after joining the SHGs their role has drastically changed in all decision areas of farm activities except land preparation, labour hiring, irrigation and purchase and sale farm machinery. SHGs members show positive impact on pattern of household consumption expenditure as average household consumption expenditure has increased significantly especially for pulses, fruits and vegetables.
\end{abstract}

Keywords: Women empowerment, self-help groups, farm activities, consumption pattern

Self-Help Group is now a well-known concept, SHGs play today a major role in poverty alleviation in rural area. It is reported that the SHGs have a role in hastening country economic Development. SHGs have now evolved as a movement, mainly women members of the SHGs are consequently, participation of women in the country economic development is increasing. They also play an important role in elevating the economic status of their families, Women constitute around fifty percent of the total human resources in our economy. This has led to boost the process of women Empowerment, yet women are subservient to men as they are subject to many socioeconomic and cultural constraints. The situation is more serve in the rural and backward areas. Women development activities must be given importance to eradicate poverty, increase the economic growth and for better standard of living, the
SHGs promotes small savings among its members, SHGs is a small voluntary association of poor People preferably from the same socio-economic background.

Women SHGs members play an important role in the field of farm activities and also play an important role while decision making related to consumption of food items necessary for them as well as their family members to lead a healthy and prosperous life. Rural women who has joined SHGs got time to time training related to saving, farm operations, health, education, inclusion of green leafy vegetables as well as food items to their diet to overcome the under nutrition that is more prevalent in

How to cite this article: Kumar, A. (2020). Study the Role of Women SHGs Members in Farm Activities and Household Consumption Pattern. Int. J. Soc. Sci., 9(03): 193-198.

Source of Support: None; Conflict of Interest: None (क) 
rural poor households etc. The member of SHGs they are gradually started getting recognition for the activities, they are performing in farm as well as the decision they are taking in their houses for improvement of livelihood and nutritional status of their family members.

The present study evaluates the SHGs impact on changing role of women in farm activities, pattern of consumption expenditure, status of loan borrowing and repayment, utilization pattern on fund, as well as allocation of household income on food and gives an insight into the village scenario. The study results will be fruitful to policy makers, administrators, researchers, academicians, and the organizations as well as individuals involved in this type of work. The specific objectives of the study are (i) to assess the role of women members in decision making in farm activities; (ii) to examine the socio-economic condition of selected household and (iii) to examine the consumption pattern of selected household, before and after joining the SHGs.

\section{Methodology}

A planned approach has been employed for data collection, so that the facts are near to realty and free for aberrations are elicited for impact evaluation. In order to attain the proposed objective. Data has been purposely obtained from two block of Patna District namely Masourhi and Dulhinbazar, from selected block randomly 20 SHGs (10 each block) identified on the basis of maturity of groups. Thus, the present study is based on 20 randomly selected SHGs, after that 5 respondents were selected from each SHGs, total 50 respondents from each Block. Thus, a sample of 100 women members was selected from 20 SHGs. The present study is empirical so data were collected by conducting a household level survey. The primary data were obtained by administering a pre-tested schedule designed for the study, and finally data were elicited from the selected respondents through conducting a personal interview. The data on rural women contribution in decision making related to farm activities, food consumption pattern and allocation of household income status in SHGs were obtained for the year 2011. The collected data from primary sources have been compiled and presented in the form of tables to make the presentation of the study more impressive.
Simple statistical tools like mean, standard deviation, averages, percentage etc. were used to get the precise result of the study.

In order to quantity the extent of SHG, women's role in decision making in various activities related to agriculture, they were asked about their degree of involvement in decision making and responses were considered on three-point scales.

The decision score was calculated by the following formula:

Decision Score $=\frac{N I .0+J F .1+I D .2}{100}$

Where,

$$
\begin{aligned}
& N I \text { - No Involvement } \\
& J D \text { - Joint Decision \& ID-Independent Decision }
\end{aligned}
$$

\section{RESULTS AND DISCUSSION}

The age wise distribution of sample has been displayed in the Table 1. It may be revealed from table that 50 per cent respondent fall in the age group of 20-35 years and 34 per cent comes under the age group of 36-50 years. Members above the age of 50 are only 16 per cent. It is therefore evident from the above analysis that the majority of respondent were young women. It is manifest from the table that vast majorities (83 per cent) are from nuclear families. It was stated during the course of interview with the members that the nuclear family system enabled them to actively participate in group activities. Results on caste categories indicate that out of 100 households of SHGs majority of the respondents belongs to backward castes (63\%) followed by SC/ST $(26 \%)$ and general (11\%). A close glance at table reveals that the respondents with literate constitute a higher percentage of 45 per cent closely followed by illiterate respondents with 29 per cent and primary schooling with 12 per cent.

The sample shows a higher percentage of respondent were doing the job of agriculture labour as the major source of income (40) followed agriculture (16), petty business (11) and others. Results on land holding revealed that majority of the respondent belongs to small \& marginal category i.e. $65 \%$ followed by medium $(30 \%)$ and large $(5 \%)$ size of holding. 
Table 1: Distribution of respondent according to their demographic characters $(n=100)$

\begin{tabular}{llll}
\hline Characteristic & Category & Frequency & Percentage \\
\hline Age & Young (20-35) & 50 & 50 \\
& Middle (36 to 50) & 34 & 34 \\
Family & Old (above 50) & 16 & 83 \\
Caste & Nuclear Family & 16 & 17 \\
& Joint family & 83 & 11 \\
Education & Forward & 17 & 63 \\
& OBC & 11 & 28 \\
& SC/ST & 63 & 32 \\
Occupation & Illiterate & 28 & 45 \\
& Literate & 32 & 12 \\
& Primary & 45 & 11 \\
& Middle & 12 & 16 \\
Size of landholding & Agriculture & 11 & 40 \\
& Agriculture Labour & 16 & 7 \\
& Service & 40 & 11 \\
& Mason, Construction work & 7 & 17 \\
& Petty business & 11 & 9 \\
& Driving, Couriers, telephone booth & 9 & 65
\end{tabular}

Source: Field Survey.

Table 2: Participation of women self-help groups members in decision-making process in relation to farm activities

\begin{tabular}{|c|c|c|c|c|c|c|c|c|c|}
\hline \multirow{2}{*}{$\begin{array}{l}\text { S1. } \\
\text { No. }\end{array}$} & \multirow{2}{*}{ Decision-making areas } & \multicolumn{4}{|c|}{ Before joining SHG $(n=100)$} & \multicolumn{4}{|c|}{ After joining SHG $(\mathrm{n}=100)$} \\
\hline & & ID & JD & NI & Score & ID & JD & $\mathrm{NI}$ & Score \\
\hline 1 & Plot selection & 10 & 30 & 60 & 0.86 & 12 & 66 & 22 & 0.90 \\
\hline 2 & Crop and Variety to be Shown & 15 & 24 & 61 & 0.54 & 15 & 73 & 12 & 1.03 \\
\hline 3 & Land Preparation & 13 & 31 & 56 & 0.56 & 15 & 54 & 31 & 0.84 \\
\hline 4 & Manure/Fertilizer Application & 15 & 31 & 54 & 0.61 & 17 & 67 & 16 & 1.01 \\
\hline 5 & Pesticide Application & 14 & 30 & 56 & 0.58 & 14 & 68 & 18 & 0.96 \\
\hline 6 & Irrigation & 9 & 18 & 73 & 0.36 & 12 & 58 & 30 & 0.72 \\
\hline 7 & Weeding & 10 & 21 & 69 & 0.41 & 15 & 64 & 21 & 0.94 \\
\hline 8 & Labour hiring & 10 & 24 & 66 & 0.44 & 12 & 56 & 32 & 0.80 \\
\hline 9 & Harvesting & 10 & 25 & 65 & 0.45 & 13 & 65 & 22 & 0.91 \\
\hline 10 & Marketing of Agric inputs \& farm produce & 20 & 13 & 67 & 0.55 & 18 & 69 & 13 & 1.05 \\
\hline \multirow[t]{3}{*}{11} & Purchase \& sale (farm Machinery) & 12 & 23 & 65 & 0.47 & 14 & 46 & 40 & 0.72 \\
\hline & Mean \pm SD & 12.55 & 24.55 & 62.91 & 0.53 & 14.27 & 62.36 & 23.36 & 0.9 \\
\hline & & \pm 3.3 & \pm 5.78 & \pm 6.01 & \pm 0.13 & \pm 2.0 & \pm 7.94 & \pm 8.85 & \pm 0.12 \\
\hline
\end{tabular}

Source: Field Survey.

Involvement of farm women as a before joining and after joining of SHGs in decision making processes in farm activities presented in Table 2 . The perusal of the results reveals that before joining the SHG groups farm women's involvement in decision making process in agriculture field quite minimal. Results indicate that plot selection, crop and variety to be shown, marketing of agri-inputs \& farm produce and manure/ fertilizer application were the activities wherein involvement was very poor. The study conducted by Nalini et al. (2013) \& Sharma et al. 
(2013) presented the almost similar results. The tasks in which farm women's participation before joining the SHG indecision making in different agriculture practices was less than 40 percent (individual decision plus joint decision) were Selection of seed variety, labour hiring, irrigation, weeding, harvesting, marketing of agri-inputs \& farm produce and purchase \&sale (farm machinery). Mishra et al. (2008) also reported that in selection of seed variety involvement of farm women was only 29 percent and in field preparation involvement was 48 percent. Involvement as non SHG farm women in harvesting operation was 35 percent only. More or less similar results were also presented by Katiyar et al. (2008) and Nalini et al. (2013) in their studies.

The most striking feature of this study was that individual decisions were taken by farm women before and after joining the SHG make not much difference in their role in almost all the farm activities. But it is worth noting that there have immense changes in their role as a joint decision maker before and after joining the SHG. Without active participation of women and incorporation of women perspectives at all levels of decision- making, the goals of equality development and peace cannot be achieved (Karl, 1995).

From this point of view, it may be suggested that women should be encouraged to take decisions and make plans jointly with their male counterparts not only to achieve the happiness \& peace of the family but also to improve to the socio-economic status of the family. It was previously also reported by Pandey et al. (2011). Farm women's less participation in agriculture decision making before joining the SHG may be due to their low self-confidence, lack of knowledge, belief that women are subordinate to male counterparts, prevalence of illiteracy, poor access of to farm information etc.

Mean (S.E.) decision-making score for the SHGs woman respondents was $0.9+0.12$ and for the women respondent as a non-SHGs member it was $0.53+0.13$. Therefore, decision making level was much higher among the woman as a SHGs member than the women as a nonSHGs member. Moreover, among the respondent's joint decisions were taken in $24.55 \%$ and $62.36 \%$ cases by the women as a non SHG and SHG members respectively and therefore, the level of joint decision making was comparatively higher among the respondent woman as a SHG member than before joining the SHGs (non SHG member).

Therefore, the decision-making score was significantly higher in the case of women members after joining the SHGs than in the case of woman before joining the SHGs. It was previously also reported by Hoque and Itohara (2008). The impact of SHG on the pattern of household consumption expenditure is presented in Table 3. In case of food items, all the items were

Table 3: Pattern of consumption expenditure in women self-help group members (₹ per month)

\begin{tabular}{llll}
\hline Food items(A) & Before joining SHG & After joining SHG & Percentage Increase \\
\hline Foods grains & 1045 & 1306 & 25 \\
Pulses & 450 & 720 & 60 \\
Vegetables & 343 & 582 & 70 \\
Fruits & 200 & 300 & 50 \\
Non-Vegetarian items & 304 & 470 & 55 \\
Milk \& milk products & 346 & 519 & 50 \\
Cooking oil and fats & 259 & 363 & 40 \\
Miscellaneous (sugar, jiggery, species, etc.) & 300 & 417 & 39 \\
Total Expenditure & 3207 & 4677 & 44 \\
\hline Non-food items (B) & & & \\
Health expenditure & 450 & 675 & 50 \\
Clothing & 952 & 1142 & 20 \\
Celebrations & 1867 & 2235 & 20 \\
Total Expenditure & 3269 & 4052 & 26 \\
Gross Expenditure & 6516 & 8719 & 35 \\
\hline
\end{tabular}

Source: Field Survey. 
showing above and around 40 per cent increase in its consumption after joining the SHG except cereals. It observed only 20 percent increase in its consumption what is the household were consuming prior to be the member of SHG. The reason behind less percent increase in consumption of cereals after joining SHG was mainly because of the fact that they were already including larger quantity of cereals in their diet.

Therefore, the minimal increase in cereals consumption with respect to other food items in the respondent households is a good sign as it helps them to diversify dietary intake. There was a lot of impact on consumption of food items such as fruits (50\%) and vegetables (70\%) after becoming the member of SHG. It was mainly because of respondent SHG women not only they were involving in saving and loan borrowing activities from the group, they were also got training time and again after interval about good habits of washing hands before cooking \& eating, after toilet, including green leafy vegetables, milk \& milk products, seasonal fruits (such as watermelon, cucumber, carrot, guava, papaya etc.) etc., in daily diets, take pulses with sour items like lemon etc to increase the consumption of protein in the body etc. Besides they were also engaged in creating awareness among the rural women regarding behaviour change whatever learnt through training, it also put great impact on SHG women which reflects in their consumption pattern itself. However, milk \& milk products have also been reported increase in its consumption but less than 50 per cent. It may be due to higher cost of milk \& its products.

In case of non-food items, all the items were showing significance increase in consumption pattern but increase after joining the SHG were less than 50 percent in all the three items considered in the present study i.e. on health expenditure, clothing and celebrations. It shows respondent farm women's due importance towards food items over non-food items. Utilization pattern of loan by women members are presented in table 4.

It reveals that the average loan amount borrowed by respondent SHG women from the group was ₹ 22789 , the average repayment of loan was ₹ 15105 (68.75\%), and overdue of loan amount was ₹ 6,988 (33.25\%). It was mainly because; all women SHGs were getting loan from the bank, which would help to lend more loans to members. Repayment performance was also good mainly because majority of respondent SHG women had to utilize the loan for the purpose it has been taken and not prefer to divert the loan amount. The details of loan utilization pattern are presented are in Table 5.

Table 4: Utilization pattern of loan by Women Members

\begin{tabular}{lll}
\hline S1. No. & Purpose & $\begin{array}{l}\text { Rank } \\
(\mathbf{1 - 6 )}\end{array}$ \\
\hline 1 & Consumption Purpose & 6 \\
2 & Health Measures & 5 \\
3 & Education & 6 \\
5 & Agriculture & 2 \\
5 & Animal husbandry (poultry, duckery, cow, & 3 \\
& buffalo rearing fishery etc.) & 3 \\
\hline
\end{tabular}

Source: Field Survey.

Table 5: Allocation of Household income on Food before and after joining the SHG by Respondent

\begin{tabular}{|c|c|c|c|c|}
\hline $\begin{array}{l}\text { Range of } \\
\text { Amount }\end{array}$ & 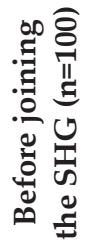 & 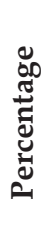 & 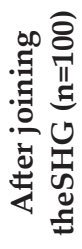 & 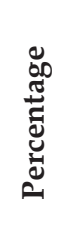 \\
\hline Less than 1000 & - & - & - & - \\
\hline $1001-2000$ & 7 & 7 & - & - \\
\hline $2001-3000$ & 37 & 37 & 4 & 4 \\
\hline $3001-4000$ & 56 & 56 & 13 & 13 \\
\hline $4001-5000$ & - & - & 71 & 71 \\
\hline More than 5000 & - & - & $12-$ & -12 \\
\hline
\end{tabular}

Source: Field Survey.

Table 5 indicated loan utilization pattern by respondent SHG women. To obtain the ranks respondents were asked to rank (1 to 6) the reasons as per suitability in their cases in a set of close ended questions. Data were computed and ranks were worked out i.e. smaller the average number against the reason higher will be the rank. Data revealed that a maximum number of borrowers availed loan for the purpose of agriculture 
followed by income generating activity, animal husbandry activities, health measures, consumption purpose and education. It is mainly due to the reason that majority of the respondent SHG women depends on agriculture as a source of their livelihoods and being a member of SHG they have undergone training about the income generating activities. The findings are in line with the results of Rangi et al. (2002).

Allocation of household income by respondent women on food before and after joining the SHG is presented in Table 5 , it was observed that $56 \%$ respondent households allocate income ranges from ₹ 3001 to 4000 followed by: ₹ 3001 to 4000 i.e. households and rupees 1001 to 2000 i.e. only $7 \%$ households on food items before joining the SHG. However, after joining the SHG 71\% respondent household started allocating income ranges from 4001 to 5000 on food items followed by: ₹ 3001 to 4000 i.e. $16 \%$ households and ₹ 2001 to 3000 i.e. 4 \% households. It shows their awareness towards inclusion of all food group items in diet to lead happy and healthy life as well as to curtail expenses on health issues.

\section{CONCLUSION}

Rural women are the major working forces of farming activities in the study area. They regularly engaged and participated in agriculture activities, working as an agriculture labour and also engaged in other activities. Despite their incredible role in agricultural sector, rural women's participation as non SHG member in farm management decision-making is found quite minimal especially in the areas of purchase/sale of farming implements, sale of farm produce, irrigation, weeding and labour hiring. But their role has drastically changed after joining the SHG in all decision areas of agricultural activities except land preparation, labour hiring, irrigation and purchase and sale of farm machinery. Farm women's less participation before joining the SHG may be due to low self-confidence, lack of knowledge, belief that women are subordinate to male counterparts, illiteracy, poor access of to farm information etc. SHGs show positive impact on the pattern of household consumption expenditure as average household consumption expenditure on food has increased significantly especially for pulses, fruits and vegetables.
Repayment performance was also found good mainly because of respondent SHG women had to utilize the loan for the purpose it has been taken and not prefer to divert the loan amount.

The results inferred that loan amount borrowed was firstly used for agriculture purposes and secondly utilized for income generating activities. It may be due to the fact that agriculture was the main source of livelihoods for respondent SHG women in the study area and as they received training for income generating activities, they prefer to invest loan amount on income generating activities too. It is also worth noting that before joining the SHG most of the respondent farm women (56\%) allocate $₹ 3001$ to 4000 on food which get increased upto ₹ 4001 to 5000 after joining the SHG. It is mainly due to increased awareness regarding importance of food diversity as well as due to increased income through improved package of practices and income generating activities. (IGA).

\section{REFERENCES}

Hussain, A.S. and Nair, A.S. 2006. Women empowerment 'Kudumlashree' projects of Kerala a micro level analysis. MANAGE Ext. Res. Review, VII(2): 23-43.

Katiyar S., Acharya G.P. and Triphathi, S.N. 2008. Role of farm women in decision making concerning farm and home activities, Rajasthan Journal of Extension Education, 16: 195-198.

Kumarm, S.S. 2011. Women empowerment and poverty reductions through self-help groups in the Nilgiri district, Golden Research Through, 1(1): 1-4.

Pandey, S., Meena, B.S., Sharma P. and Dwivedi, R.N. 2011. Gender Involvement in Decision Making off and farm Activities. Journal of Community Mobilization and Sustainable Development, 6(1): 042-045.

Rangi, P.S., Sidhu, M.S. and Hajit Singh, 2002. Economics empowerment of rural women through self helps groups: A case study of Fategarh Sahib District (Punjab). Man and Develop, 24(3): 65-78.

Sharma, S., Rao, P.K. and Sharma, R. 2013. Role of women in decision making related to farm: A study of Jammu district of $\mathrm{J} \&$ State, International journal of Scientific and Research Publications, 3(1): 1-4. 